\title{
PERHITUNGAN MARGIN TERHADAP PEMBIAYAAN BACK TO BACK PADA PT. BANK MUAMALAT INDONESIA CABANG PADANG
}

\author{
Desi Nirmala Putri, Jhon Fernos \\ Akademik Keuangan dan Perbankan "Pembangunan" Padang \\ desinputri8@gmail.com
}

\begin{abstract}
This study aims to discuss how the margin calculation for refinancing at PT. Bank Muamalat, Padang branch. This analysis uses descriptive quantitative data expressed in the form of numerical results in an example of one sample, as well as descriptions from interviews with back to back financing margin calculations. This research sample was taken from one of the customers of PT. Bank Muamalat, Padang branch. The results of this study indicate the calculation of the refinancing margin at PT. Bank Muamalat Padang branch uses the annuity method to make a profit. The margin income earned from the customer is different every month and gets smaller, but the amount of payment from the installment principal plus the margin that the customer receives each month remains the same by increasing the principal amount every month.
\end{abstract}

Keywords: bank, margin back to back

\section{PENDAHULUAN}

Dalam perkembangan ekonomi di bidang industry keuangan islam telah ada sejak zaman-Nya Rasullulah dengan menggunakan konsep murabahah atau kemitraan yang dilakukan oleh umat muslim selama berabad-abad. Tonggak pergerakan perbankan syariah sendiri baru didirikan oleh Ahmed Al Najjar pertama kali di Mesir pada tahun 1963 yang diberi nama Myt-Ghamr Bank. Perbankan ini tidak membebankan bunga pada setiap transaksi melainkan berbasis profit sharing (pembagian keuntungan). Berdasarkan prinsip muamalah, MytGhamr Bank dinilai berhasil menggabungkan manajemen perbankan konvensional dengan prinsip syariat Islam dalam mengaplikasikan produk yang dikeluarkan oleh bank syariah.

Kegiatan yang dilakukan antara kedua bank ini tidak jauh berbeda namun yang membedakan ialah cara dan proses kerja yang dilaksanakannya. Bank konvensional adalah lembaga keuangan yang menjalankan bisnis baik dalam menawarkan produk jasa maupun memberikan transaksi lalu lintas pembayarannya selalu menerapkan metode bunga dalam mendapakan keuntungan. (Agus Marimin, Abdul Haris Romdhoni, 2015)

Sedangkan dalam undang-undang pasal 2 Peraturan Bank Indonesia, bank syariah adalah lembaga kuangan yang menjalankan operasionalnya berlandaskan 
prinsip syariah tanpa bunga dengan melakukan pengimpunan, menyalurkan dana pada masyarakat hingga memberikan jasa lalu lintas pembayaran. (Fetria, 2014)

Dalam meningkakan kondisi ekonomi suatu bank maka bank syariah memberikan layanan pembiayaan bagi nasabah yang kekurangan dana dalam memenuhi kebutuhan finansialnya sehingga bank mendapat margin dari kemitraan yang dilakukan bersama nasabah. Pembiayaan yang diberikan oleh bank syariah dapat berupa pembiayaan konsumtif maupun produktif. (Ilyas, 2015)

Setiap bisnis yang dijalankan pasti mempunyai resiko dan untuk mengurangi resiko yang terlalu besar bank syariah mengeluarkan suatu produk pembiayaan yang di rasa tidak memiliki resiko yang terlalu tinggi. Pembiayaan ini dikenal dengan pembiayaan back to back atau pembiayaan murabahah.

Menurut peraturan MA tahun 2008 dalam hukum ekonomi syariah, pembiayaan murabahah merupakan pembiayaan yang dilakukan dengan transaksi jual beli dengan menyatakan pembelian barang terdapat harga lebih atau perolehan keuntungan yang disepakati bersama dan saling menguntungkan dimana pengembaliannya dapat diangsur sesuai dengan batas waktu. (Hakim Lukmanul, 2017)

Mengingat agunan yang dijaminkan nasabah bisa berupa asset liquid salah satunya bisa deposito, dimana deposito merupakan simpanan berjangka yang dapat di cairkan dengan waktu jatuh tempo. Jaminan dengan deposito ini di rasa tidak memiliki resiko yang terlalu tinggi karena dapat langsung dicairkan dengan uang tunai. Pembiayaan ini juga tidak mengancam posisi simpanan debitur karena keuntungan yang diperoleh nasabah dari bagi hasil deposito dapat digunakan untuk mengcover sebagian cicilan pembiayaan tersebut. Berikut ini dapat dilihat data nasabah peminat produk pembiayaan back to back pada PT. Bank Muamalat Cabang Padang

Tabel 1

Perkembangan Pembiayaan back to back Pada PT. Bank Muamalat Indonesia Cabang Padang

Tahun 2019 - 2020.

( dalam Rp. 000 )

\begin{tabular}{rccc}
\hline No & Tahun & Jumlah Nasabah & Jumlah \\
\hline 1 & 2017 & 26 & $6,099,526,656,38$ \\
2 & 2018 & 26 & $7,343,600,723,00$ \\
3 & 2019 & 27 & $5,391,108,936,08$ \\
4 & 2020 & 25 & $5,747.018,936,30$ \\
\hline & Jumlah & 104 & $2,458125,443,976$ \\
\hline
\end{tabular}

Sumber : PT. Bank Muamalat Cabang Padang

Dari tabel 1.1 diatas, pada tahun 2017 ke 2018 pembiayaan back to back belum mengalami peningkatan pada jumlah nasabahnya tetapi angka pembiayaan yang diberikan oleh bank kepada nasabah pada tahun 2018 cukup besar dibandingkan dengan tahun 2017. Kemudian pada tahun 2019 pembiayaan back to back meningkat pada jumlah nasabahnya menjadi 27 orang nasabah dan tahun 2020 hingga akhir juni memiliki nasabah pembiayaan back to back mencapai 25 orang. 
Dari latar belakang diatas maka penulis terarik untuk melakukan penelitian tentang pembiayaan back to back pada PT. Bank Muamalat Indonesia Cabang Padang. Berdasarkan data nasabah dari tahun ke tahun yang tidak menampakkan perubahan yang cukup besar maka produk ini masih dianggap kurang mendapat perhatian dari sebagian nasabah pembiayaan, dimana pembiayaan back to back ini bisa digunakan untuk kegiatan produktif yang menggunakan akad murabahah (jual beli). Presentase yang diperoleh bank dari produk yang dijualnya melalui perhitungan margin dimana keuntungan bank telah ditetapkan diawal.

Sebab itu, penulis sangat tertarik untuk mengangkat judul "Sistem Perhitungan Margin Terhadap Pembiayaan Back To Back Pada PT. Bank Muamalat Indonesia Cabang Padang" Untuk dilakukan penelitian berdasarkan ilmu yang telah di dapat selama proses magang di PT. Bank Muamalat Indonesia Cabang Padang dan pengetahuan selama belajar di kampus AKBP.

\section{METODE PENELITIAN}

Dalam melaksanakan penelitian penulis menggunakan metode kuanitatif deskripif, dimana metode tersebut menggabungkan penelitian yang diambil dari lapangan dan perpustakaan.

a. Perpustakaan (Library Research)

Penulis melaksanakan penelitian dengan membaca literatur serta mencari referensi melalui buku maupun ineternet dengan mendownloand jurnal sebagai bahan uraian teoritis.

b. Lapangan (Field Research)

Penelitian ini dilakukan oleh penulis dengan terjun langsung Ke PT. Bank Muamalat Cabang Padang dengan cara mendapatkan data secara terulis (bentuk file) maupun lisan (interview) mengenai data yang diperlukan.

\section{HASIL DAN PEMBAHASAN}

Perhitungan margin terhadap pembiayaan back to back pada PT. Bank Muamalat Indonesia Cabang Padang

a. Pembiayaan Back To Back Pada PT. Bank Muamalat Indonesia Cabang Padang

Berdasarkan data yang diperoleh dari PT. Bank Muamalat Indonesia cabang Padang, Pembiayaan back to back merupakan produk pembiayaan yang diberikan kepada nasabah dalam bentuk pembelian apapun bersifat keperluan produktif dalam konten halal. PT. Bank Muamalat Cabang Padang dalam memberikan pembiayaan back to back menggunakan akad murabahah atau akad jual beli. Pada pembiayaan ini jaminan yang dijadikan sebagai agunan bisa berupa asset yang paling liquid atau muda dicairkan seperti giro, deposio, obligasi maupun surat berarga lainnya. Asset yang dijadikan sebagai agunan wajib atau harus tersimpan pada PT. Bank Muamalat. Selama pembiayaan ini belum lunas, asset akan dipegang penuh oleh bank seperti barang gadai. Jika sewaktu-waktu nasabah mengalami macet atau tidak sanggup bayar maka pihak bank akan mencairkan agunannnya untuk menutupi hutang sesuai dengan sisa hutang tersebut dan mengembalikan sisanya apabila melebihi hutang. Saat ini pembiayaan back to back lebih 
banyak menggunakan deposito sebagai jaminannya karena lebih mudah dicairkan dalam bentuk tunai.. Jadi pembiayaan back to back ini sangat menguntungkan selain menjaga asset tetap utuh, nasabah masih dapat melakukan pinjaman dan pembayaran cicilannya dapat diperoleh dari pendapatan bagi hasil setiap bulan deposito nasabah. Dibawah ini dapat dilihat data nasabah yang melakukan pembiayaan back to back pada PT. Bank Muamalat Indonesia cabang Padang.

\section{Tabel 2}

Perkembangan Pembiayaan back to back

Pada PT. Bank Muamalat Indonesia Cabang Padang

Tahun 2019 - 2020.

( dalam Rp. 000 )

\begin{tabular}{cccc}
\hline No & Tahun & Jumlah Nasabah & Jumlah \\
\hline 1 & 2017 & 26 & $6,099,526,656,38$ \\
2 & 2018 & 26 & $7,343,600,723,00$ \\
3 & 2019 & 27 & $5,391,108,936,08$ \\
4 & 2020 & 25 & $5,747.018,936,30$ \\
\hline & Jumlah & 104 & $2,458125,443,976$ \\
\hline
\end{tabular}

Sumber : PT. Bank Muamalat Cabang Padang

Selama 3 tahun 6 bulan ini peminat nasabah yang melakukan pembiayaan pada PT.bank Muamalat Indonesia cabang padang sudah mencapai 104 orang nasabah dengan jumlah pemberian pembiayaan yang di keluarkan bank mencapai sebesar Rp. 2,458125,443,976

b. Mekanisme pembiayaan back to back

Dalam proses mengajukan pembiayaan back to back calon nasabah wajib mengikuti ketentuan pelaksanaan yaitu sebagai berikut:

1. Permohonan pembiayaan

Nasabah yang ingin melakukan pinjaman melalui pembiayaan back to back harus mengajukan permohonan terlebih dahulu. Pada pertemuan pertama seorang marketing harus mampu memberikan informasi yang dibutuhkan oleh nasabah. Nasabah yang berminat harus mampu memenuhi dokumen. Dokumen yang dipersyaratkan untuk lanjut ke langkah persetujuan antara lain yaitu:

a. Melengkapi dokumen sebelum komite pembiayaan seperti:

1) Asli form aplikasi permohonan pembiayaan standar BMI

2) Copy KTP calon nasabah

3) Copy NPWP Nasabah

4) Asli MUP Pembiayaan khusus pembiayaan beragunan tunai

5) Asli Bank Checking

6) Dokumen kebutuhan pembiayaan(hanya untuk plafond > Rp. 10M)

b. Melengkapi dokumen sebelum akad pembiayaan

1) Asli form aplikasi permohonan pembiayaan standar BMI

2) Copy KTP calon nasabah, copy NPWP nasabah

3) Asli MUP Pembiayaan khusus pembiayaan beragunan tunai

4) Asli BI Checking 
5) Persetujuan Pasangan

6) Copy KTP pasangan Nasabah dan Copy Kartu Keluarga (KK) nasabah

7) Copy Akta Nikah/Akta Perkawinan (jika menikah)

8) Asli Copy Akta Cerai/Akta Perceraian (jika cerai hidup) atau Asli surat Kematian dari

9) RS/Puskesmas/Kelurahan (jika pasangan nasabah meninggal) atau Asli surat pernyataan belum

10) Copy KTP pemilik agunan dan KTP pasangan pemilik agunan (jika deposito bukan milik nasabah)

11) Copy NPWP Pemilik agunan (jika deposito bukan milik nasabah)

12) Copy Kartu Keluarga (KK) Pemilik agunan (jika deposito bukan milik nasabah)

13) Copy Akta Nikah/Akta Perkawinan pemilik agunan yang telah menikah (jika deposito bukan milik nasabah)

14) Copy putusan pembagian harta gono gini pemilik agunan dari pengadilan agama (jika pemilik agunan statusnya cerai hidup dan menggunakan agunan harta bersama)

15) Bilyet/Advis Deposito (ASLI)/ Buku Tabungan TPB (ASLI)/ Print out Nomor rekening Giro Escrow berdasarkan screen di report MARS

16) Surat Kuasa Blokir/Hold dan Buka Blokir Deposito/Giro/TPB

17) Surat Kuasa Pencairan agunan tunai

18) Asli Lembar Keputusan Komite Pembiayaan

19) Asli Form Permohonan Pemblokiran Deposito atau hold giro/TPB

20) Asli underlying dokumen akad pembiayaan

21) Print out nomor rekening agunan di MCB (jika cabang penerbit agunan berbeda dengan cabang pemberi pembiayaan)

22) Surat kuasa pendebetan/pencairan yang ditandatangani oleh Nasabah dan pasangan

2. Persetujuan pembiayaan

Berkas yang diberikan nasabah kepada pihak bank harus dilakukan analisa serta menverifikasi kepada penjabat yang berwenang sehingga dapat diambil tindakan persetujuan sesuai hasil analisa yang telah dilakukan.

3. Pengikatan pembiayaan

Setelah data yang diajukan nasabah disetujui, pihak bank dan nasabah harus melakukan pengikatan pembiayaan terkait besarnya pinjaman yang diajukan serta melakukan pengikatan akad pembiayaan

4. Pengikatan agunan

pinjaman yang dilakukan harus mengikatkan sesuatu sebagai barang jaminan dalam upaya mengendaliakan resiko apabila terjadi wanprestasi serta memiliki kekuatan hukum. 


\section{Pemblokiran jaminan}

Setelah melalui pengikatan agunan bersama legal dan ditandatangani hukum oleh notaries penjabat, agunan yang dijadikan sebagai jaminan harus dipegang penuh oleh pihak bank

6. Pencairan pembiayaan

Berkas yang lengkap dan telah disetujui oleh pihak bank maka akan dilakukan pelaporan kepada kantor pusat untuk dilakukan dropping atau pencairan danaatas pembiayaan nasabah

7. Dokumentasi

Berkas-berkas lengkap nasabah mengenai pembiayaan back to back ini akan dilakukan penyimpanan oleh legal dan admin custody

8. Pemantauan

Pada bank syariah dana yang diberikan akan dipantau perkembangannya oleh pihak bank supaya mengetahui kondisi cicilan yang akan dilakukan selanjutnya

9. Tindak lanjut defaul (jika terjadi default)

apabila terjadi kolektibilitas maka akan dilakukan tindak lanjut terhadap nasabah tersebut

10. Pembukaan hold/blokir, pelunasan dan pelepasan jaminan

Setelah angsuran pembiayaan lunas maka akan dilakuka pembukaan jaminan atas barang yang dijadikan agunan.

c. Perhitungann pembiayaan back to back

Melalui aplikasi pembiayaan yang menjaminkan deposito sebagai agunan, PT. Bank Muamalat Cabang Padang menggunakan metode anuitas untuk menghitung margin yang diperolehnya.

Rumus metode anuitas:

Angsuran bulanan »Pl $\times\left(\frac{\mathrm{i}}{12}\right) \times \frac{1}{\left(1-\left[\frac{1}{1+\left(\frac{i}{12}\right)}\right]^{m}\right)}$

Margin » $P l \times\left(\frac{\mathrm{i}}{12}\right)$

Pokok angsuran » Total angsuran - Margin

Keterangan $\gg \mathrm{Pl}:$ plafon

i : rate margin

m : jumlah periode pembayaran

berikut ini ilustrasi perhitungan margin pembiayaan back to back di PT. Bank Muamalat Cabang Padang.

Ibu widia mengajukan pinjaman pembiayaan back to back sebesar Rp. 500.000.000 dan harga jual bank yang telah disepakati sebesar Rp.517.778.501.76 dalam jangka waktu 1 tahun atau 12 bulan.

Dari contoh tersebut dapat diketaui :

Pl : 500,000,000

i : $6,10 \%$

$\mathrm{m}: 12$ bulan 
Perhutungan margin pembiyaan menggunakan metode anuitas yaitu: diketaui :

Angsuran bulanan » 500.000.000 x $\left(\frac{6,50 \%}{12}\right) \times$

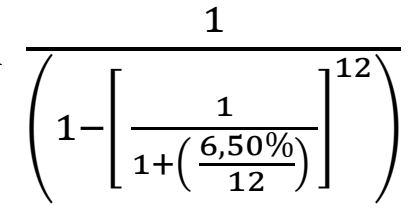

$$
=500.000 .000 \times\left(\frac{0,065}{12}\right) \times \frac{1}{\left(1-\left[\frac{1}{1+\left(\frac{6,50 \%}{12}\right)}\right]^{12}\right)}
$$$$
=500.000 .000 \times(0,005417) \times
$$$$
\overline{\left(1-\left[\frac{1}{1+(0,005417)}\right]^{12}\right)}
$$$$
=500.000 .000 \times(0,005417) \times \frac{1}{\left(1-\left[\frac{1}{1+(0,005417)}\right]^{12}\right)}
$$$$
=500.000 .000 \times(0,005417) \times \frac{1}{\left(1-[0,994613]^{12}\right)}
$$$$
=500.000 .000 \times(0,005417) \times \frac{1}{0,0622768}
$$$$
=500.000 .000 \times(0,005417) \times \frac{1}{0,0622768}
$$$$
=2708333 \times 15,93165
$$$$
=43,148,208
$$

margin perbulan » 500.000.000 $\mathrm{x}\left(\frac{6.50 \%}{12}\right)$

$$
\begin{aligned}
& =500.000 .000 \times(0,005417) \\
& =2708333
\end{aligned}
$$

Pokok angsuran » Total angsuran - Margin

$$
\begin{aligned}
& =43.148 .208 .48-2.708 .333 .333 \\
& =40439875.15
\end{aligned}
$$

\begin{tabular}{|c|c|c|c|}
\hline Pokok & margin & Angsuran bulanan & Sisa pokok \\
\hline 40439875.15 & $2,708,333.33$ & $43,148,208.48$ & 459560125 \\
\hline 40658924.47 & $2,489,284.01$ & $43,148,208.48$ & 418901200 \\
\hline 40879160.31 & $2,269,048.17$ & $43,148,208.48$ & 378022040.1 \\
\hline 41100589.1 & $2,047,619.38$ & $43,148,208.48$ & $336,921,451$ \\
\hline 41323217.29 & $1,824,991.19$ & $43,148,208.48$ & $295,598,234$ \\
\hline 41547051.38 & $1,601,157.10$ & $43,148,208.48$ & $254,051,182$ \\
\hline 41772097.91 & $1,376,110.57$ & $43,148,208.48$ & $212,279,084$ \\
\hline 41998363.44 & $1,149,845.04$ & $43,148,208.48$ & $170,280,721$ \\
\hline 42225854.57 & $922,353.91$ & $43,148,208.48$ & $128,054,866$ \\
\hline 42454577.95 & $693,630.53$ & $43,148,208.48$ & $85,600,288$ \\
\hline 42684540.25 & $463,668.23$ & $43,148,208.48$ & $42,915,748$ \\
\hline 42915748.18 & $232,460.30$ & $43,148,208.48$ & 0 \\
\hline \multicolumn{4}{|c|}{ TOTAL } \\
\hline $\mathbf{5 0 0 0 0 0 0 0 0}$ & $\mathbf{1 7 7 7 8 5 0 1 . 7 6}$ & $\mathbf{5 1 7 , 7 7 8 , 5 0 1 . 7 6}$ & $\mathbf{5 0 0 0 0 0 0 0 0}$ \\
\hline
\end{tabular}


Dari hasil data yang didapat, Bank Muamalat Cabang Padang menggunakan metode anuitas dalam menghitung margin yang diperoleh oleh bank dengan tingkat rate margin sebesar $6.50 \%$. metode ini mempereroleh hasil pendapatan margin yang setiap bulanya berbeda-beda, dimana pada bulan pertama margin yang diperoleh sebesar Rp. 2.708.333.333 dan untuk pendapatan margin bulan berikutnya dapat dikali berdasarkan seberapa besar sisa jumlah pokok angsuran yang tersisa. Namun besarnya angsuran pokok setiap bulann berubah semakin besar dan angsuran margin semakin megecil sedangkan total angsurannya tetap. Pada bulan pertama perhitungan pokok angsurannya dapat dilihat dari pengurangan antara total angsuran dengan margin yang diperoleh yaitu sebesar 40.439.875.15 dan bulan selanjunya juga dighitung berdasarkan pengurangan dari angsuran bulanan dengan margin yang didapat oleh bank.

\section{SIMPULAN}

1. Pada PT. Bank Muamalat Cabang Padang pembiayaan back to back merupakan pembiayaan yang diberikan kepada nasabah dalam bentuk pembiayaan produktif dengan akad jual beli dan lebih sering menjadikan deposito sebagai agunan yang di jaminkannya

2. Mekanisme pembiayaan pada PT. Bank Muamalat Cabang Padang harus memenuhi ketentuan pelaksanaan sebagai berikut: permohonan pembiayaan, persetujua pembiayaan, pengikatan pembiayaan, pengikatan agunan, pemblokiran jaminan, pencairan pembiayaan, dokumentasi (safe keeping ), pemtauan, tindak lanjut default (jika ada), dan pelepasan jaminan .

3. ilustrasi perhitungan margin pembiayaan back to back di PT. Bank Muamalat Cabang Padang.

Ibu widia mengajukan pinjaman pembiayaan back to back sebesar Rp. 500.000.000 dan harga jual bank yang telah disepakati sebesar Rp.517.778.501.76 dalam jangka waktu 1 tahun atau 12 bulan.

berdasarkan perhitungan metode anuitas dengan rate margin $6,50 \%$ maka perhitungan margin yang di dapat setiap bulanya berubah rubah semakin mengecik dan pokok angsuran yang semakin membesar namun angsuran yang dibayarkan perbulan tetap sama jadi perhitungan margin selama setahun. Perolehan margin selama satu bulan pertama sebesar RP. 2,708,333.33 dan perhitungan selanjutnya akan disesuai kan dengan sisa pokok yang tersisa termasuk pokok angsuran nya akan mengikuti perubahan dari besarnya nya margin.

\section{UCAPAN TERIMA KASIH}

1. kedua orang tua yang senantiasa merawat dan mendidik serta mencurahkan kasih dan sayangnya pada penulis

2. direktur AKBP beerta prodi AKBP serta bapak ibu dosen yang telah mendidik dan memberikan ilmu pengetahuan kepada penulis

3. pimpinan PT. Bank Muamalat cabang Padang yang telah mengizinkan penulis memperoleh informasi

4. serta semua pihak yang telah membantu penulis dalam penyelesaian artikel ini. 


\section{DAFTAR PUSTAKA}

Agus Marimin, Abdul Haris Romdhoni, dan T. N. F. (2015). Perkembangan Bank Syariah Di Indonesia. 01,77.

Alanshari, F., \& Marlius, D. (2018). Prosedur Pemberian Kredit KPR Pada PT. Bank Tabungan Negara (Persero) TBK Cabang Pembantu Bukittinggi. https://doi.org/10.31227/osf.io/rsfhc

Amelia, L., \& Marlius, D. (2018). Pengendalian Kredit Dalam Upaya Menciptakan Bank Yang Sehat Pada PT. Bank Pembangunan Daerah Sumatera Barat Cabang Utama Padang. https://doi.org/10.31227/osf.io/kpc64

Anto, A., \& Firmansyah, M. A. (2019). Manajemen Bank Syariah. (Qiara Medi, Issue September). CV. Penerbit Qiara Media

Budiman, J., \& Susanty, Y.F (2014). Analisis Komparatif Penerapan Suku Bunga Kpr Bank di Batam. Jurnal Manajemen Maranatha, 14(1), 97. https://doi.org/10.28932/jmm.v14il.75

Diana yumanita, a. (2010). Bank Syariah: Gambaran Umum Bank Syariah journal (Vol.14, Issue 14). http://www.bi.go.id/id/tentang-bi/bi-dan publik/kebanksentralan/Documents/14. Bank Syariah Gambaran Umum.pdf

Fetria, yudiana eka. (2014). Bank Syariah (Mochlasin). Stain Salatiga Press.

Hakim Lukmanul, A. A. (2017). Peran Baitul Maal Tanwil Husnanyain Terhadap Perkembangan Usaha Mikro (Kecil Dan Menengah). AlUrban, 2(1), 218. https://doi.org/10.22236/Al-Urban

Ilyas, R. (2015). Konsep Pembiayaan Dalam Perbankan Syariah. Jurnal penelitian, 9(1), 194. https://doi.org/10.21043/jupe.v9il.859

Nurtantia, R. (2014). Analisa Kebijakan Dalam Penetapan Margin Pada Pembiayaan Murabahah Di PT. Bprs Amanah Ummah. Nurtantia Rosyida. 5(1), 141.

Suhendri, A., \& Muklishin, A. (2018). Dimensi Ekonomi Islam Dalam Sistem Pembiayaan Bank Syariah. Jurnal iqtisaduna, 4(1), 2. Https://doi.org/10.24252/iqtisaduna.v4ilal

Umam, K. (2010). Peningkatan Keatan Syariah Melalui Pemisah (Spin-Off) Unit Usaha Syariah Bank Umum Konvensional. Mimbar hukum, 22(3), 619. Https://doi.org/10.22146/jmh.16239 
Yusman, A. D. M. (2017). Prinsip-Prinsip Tentang Perbankan Syariah Hubungannya Dengan Otoritas Jasa Keuangan. VI(1), 40. 